\title{
Inventarisasi Jenis-Jenis Kadal (Sub Ordo Sauria) di Kawasan Hutan Primer, Hutan Sekunder dan Pemukiman di Desa Parek Kacamatan Air Besar Kabupaten Landak
}

\author{
Jepri Noperese ${ }^{1}$, Ari Hepi Yanti ${ }^{1}$, Tri Rima Setyawati ${ }^{1}$ \\ ${ }^{1}$ Program Studi Biologi, Fakultas MIPA, Universitas Tanjungpura, ${ }^{\text {l. }}$ Prof. Dr. H. Hadari Nawawi, Pontianak, \\ Email korespondensi : jepri.cs678@gmail.com
}

\begin{abstract}
Parek Village Air Besar District Landak Regency has two types of forests, primary forest and secondary forest. Parek villagers generally open forests for farming, the activities of these residents can disrupt the existence of the Sauria Sub-Order. The purpose of this study was to determine the species of Sauria Sub-Order in Parek Village. The research was conducted by exploration method which was combined with the line transect method in the area of primary forest, secondary forest and settlement. The results of the study found 7 species from the Sauria Sub-Order there are Gonocephalus borneensis, Tachydromus sexlineatus, Cyrtodactylus sp., Hemidactylus sp., Draco sp., Eutropis multifasciata and Apterygodon vittatum which belong to 4 families, Scincidae, Gekkonidae, Agamidae and Lacertidae.
\end{abstract}

Keywords: Inventarisasi, Parek Village, Sauria, Eutropis multifasciata

\section{PENDAHULUAN}

Indonesia merupakan negara yang memiliki keanekaragaman hayati yang cukup tinggi. Sekitar $16 \%$ (600 jenis) reptil di dunia dapat ditemukan di Indonesia (BAPPENAS, 1993), dan 73 jenis diantaranya terdapat di Kalimantan. Keragaman jenis reptil yang begitu besar, belum banyak diketahui oleh masyarakat, sehingga informasi tentang jumlah jenis, aspek biologi, kegunaan dan konservasinya sangat kurang.

Kadal (Sub Ordo Sauria) merupakan anggota reptil yang tersebar pada berbagai tipe habitat di dataran tinggi maupun dataran rendah (Hickman et al., 2003). Menurut Endarwin (2006), sifat hidup reptil adalah fosorial, arboreal, terestrial dan akuatik, namun sebagian besar anggota Sub Ordo Sauria memiliki sifat hidup terestrial (famili Scincidae) dan arboreal (famili Agamidae dan Gekkonidae).

Keberadaan anggota Sub Ordo Sauria di Kalimantan Barat cukup beragam, terlihat dari penelitian Apriyanto et al. (2015), yang menemukan enam spesies kadal dari empat famili (Scincidae, Gekkonidae, Lacertidae dan Agamidae) di kawasan hutan Kecamatan Sungai Ambawang. Penelitian Amri et al. (2015), di Kawasan Hutan Lindung Gunung Semahung di Kabupaten Landak menemukan sebanyak sepuluh jenis kadal yang termasuk dalam tiga famili yaitu Agamidae, Gekkonidae dan Scincidae.

Desa Parek Kecamatan Air Besar Kabupaten Landak memiliki dua tipe hutan, yaitu hutan primer dan hutan sekunder. Untuk memenuhi kebutuhan ekonomi sehari-hari, umumnya masyarakat Desa Parek melakukan pembukaan hutan dengan pembakaran untuk berladang. Sistem berladang dilakukan dengan berpindah-pindah. Lahan yang sebelumnya dijadikan ladang selanjutnya dijadikan lahan perkebunan lada. Menurut Yusuf (2008), kegiatan alih fungsi lahan dari hutan manjadi perkebunan dan ladang dengan cara pembakaran yang tidak teratur dapat menjadi ancaman bagi keberadaan anggota Sub Ordo Sauria di wilayah tersebut. Pembukaan lahan dengan pembakaran menyebabkan satwa masuk ke pemukiman dan melakukan aktivitas pada pohon-pohon sekitar pemukiman tersebut. Oleh karena itu perlu dilakukan penelitian mengenai kekayaan jenis Sub Ordo Sauria di Desa Parek Kecamatan Air Besar Kabupaten Landak.

Tujuan dari penelitian ini adalah mengetahui jenisjenis anggota Sub Ordo Sauria yang terdapat di kawasan hutan primer, hutan sekunder dan pemukiman di Desa Parek.

\section{BAHAN DAN METODE}

\section{Waktu dan Tempat Penelitian}

Penelitian dilaksanakan pada bulan April hingga Mei 2018, di Desa Parek Kecamatan Air Besar Kabupaten Landak. Identifikasi dan pengolahan data dilaksanakan Laboratorium Zoologi Fakultas Matematika dan Ilmu Pengetahuan Alam (FMIPA), Universitas Tanjungpura, Pontianak. 


\section{Deskripsi Lokasi}

Desa Parek merupakan salah satu desa yang terdapat di Kecamatan Air Besar yang memiliki kawasan hutan dengan kerapatan vegetasi yang tinggi. Kecamatan Air Besar masuk dalam wilayah administratif Kabupaten Landak (Gambar 1).

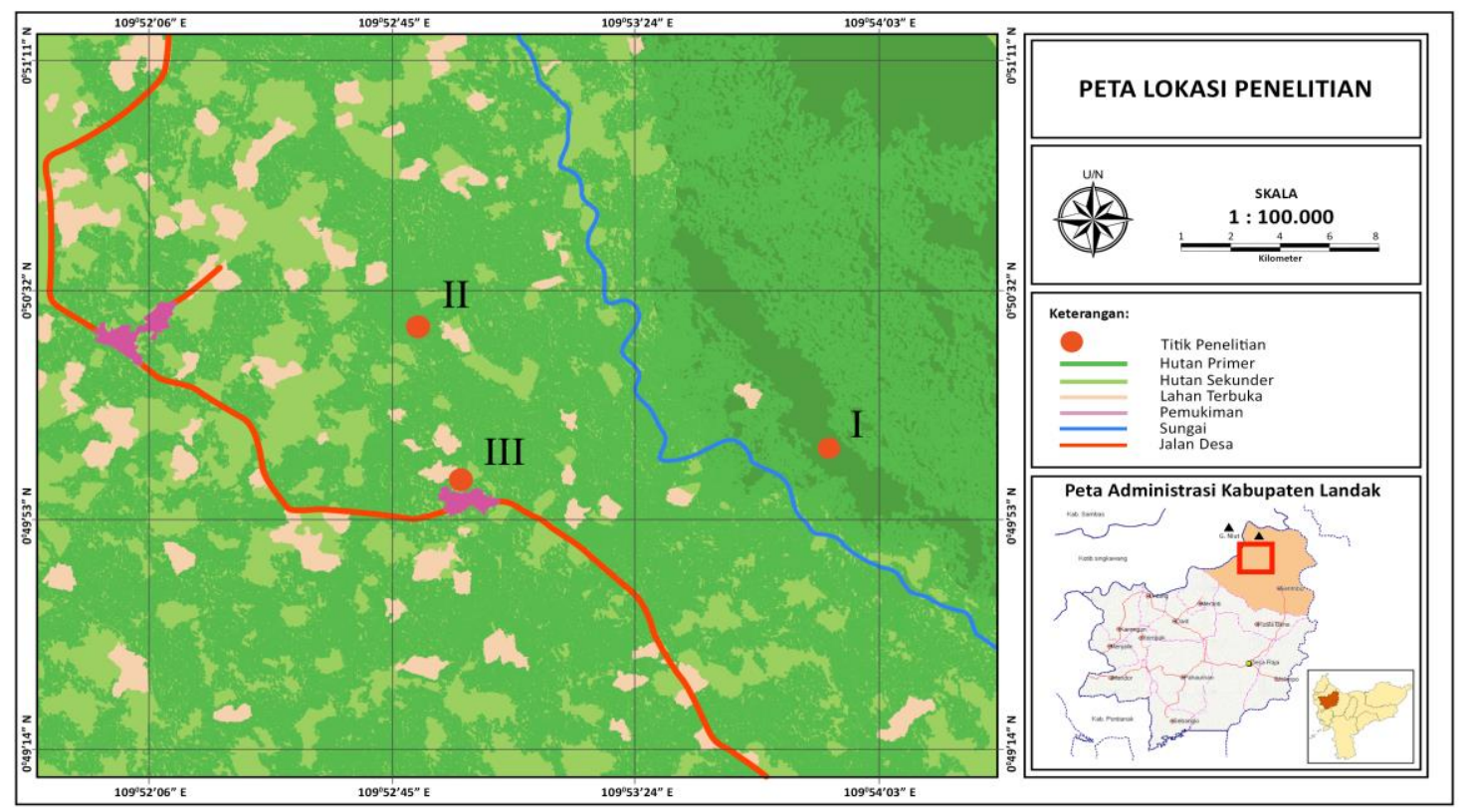

Gambar 1. Peta stasiun penelitian berdasarkan mapsource (2016)

\section{Alat dan Bahan}

Alat-alat yang digunakan dalam penelitian ini adalah buku catatan, GPS, kamera, milimeter blok, penggaris/meteran jahit, plastik packing, pinset, spidol permanen, senter, tali, termohigrometer dan termometer. Bahan-bahan yang digunakan dalam penelitian ini adalah alkohol $70 \%$ dan formalin $4 \%$.

\section{Metode Penelitian}

Penelitian ini dilakukan di Desa Parek pada kawasan hutan primer, hutan sekunder dan pemukiman (Tabel 1).

Tabel 1. Titik Koorinat Dan Rona Lingkungan

\begin{tabular}{|c|c|c|}
\hline Stasiun & Titik Koordinat & Vegetasi dan Rona Lingkungan \\
\hline 1 & $\begin{array}{l}\text { N } 00^{\circ} 50^{\prime} 28,6^{\prime \prime} \\
\text { E } 109^{\circ} 53^{\prime} 46,8^{\prime}\end{array}$ & $\begin{array}{l}\text { berada di lereng gunung yang memiliki tutupan kanopi yang rapat } \\
\text { dengan komposisi jenis vegetasi yang beragam dan termasuk hutan } \\
\text { primer }\end{array}$ \\
\hline 2 & $\begin{array}{l}\text { N } 00^{\circ} 50^{\prime} 33.9^{\prime \prime} \\
\text { E } 109^{\circ} 52^{\prime} 49.1 ”\end{array}$ & $\begin{array}{l}\text { Berada di hutan perkebunan karet (Agroforest karet) dan } \\
\text { merupakan hutan sekunder }\end{array}$ \\
\hline 3 & $\begin{array}{l}\text { N } 00^{\circ} 50^{\prime} 04.1^{\prime \prime} \\
\text { E } 109^{\circ} 52^{\prime} 56.8^{\prime \prime}\end{array}$ & $\begin{array}{l}\text { Berada di dekat area pemukiman yang memiliki kawasan terbuka } \\
\text { dan aktivitas manusia yang padat }\end{array}$ \\
\hline
\end{tabular}

Metode yang dilakukan dalam penelitian ini yaitu metode jelajah yang dipadukan dengan transek garis sejauh 1000 meter. Metode ini dilakukan dengan melakukan pencarian di sepanjang transek tersebut. Pengambilan dan pengumpulan sampel kadal dilakukan tiga kali dalam sehari, yaitu pagi hari (pukul 07.00-09.00 WIB), siang hari (pukul 12.3014.30 WIB) dan malam hari (18.30-20.30 WIB), dengan interval waktu satu minggu selama satu bulan. Preparasi kadal yang tertangkap kemudian dimasukkan ke dalam kantung spesimen yang diberi label. Kadal selanjutnya diawetkan dengan menggunakan formalin $4 \%$ dengan menyuntikannya pada ventral kemudian disimpan dalam wadah berisi alkohol 70\%. Anggota sub ordo sauria yang ditemukan diamati morfologi (morfometri dan meristik), morfometri yang diukur meliputi panjang mulut (PM), panjang aksilla (PA), panjang tubuh (PT), panjang ekor (PE), panjang humerus $(\mathrm{PH})$, panjang radius $(\mathrm{PR})$, panjang femur (PF) dan panjang tibia (PTi). 
Hasil yang diperoleh dalam penelitian ini akan dianalisis indeks frekuansi kehadiran (FR) dan indeks similaritas (S).

a. Frekuensi Kehadiran

$\mathrm{FR}=\frac{\text { jumlah lokasi suatu jenis }}{\text { jumlah total lokasi }} \times 100 \%$ (Odum, 1971 )

b. Indeks Similaritas

$$
\mathrm{S}=\frac{2 c}{A+B} \times 100 \% \quad \text { (Odum, 1971) }
$$

Ket :

S : Koefisiaen kesamaan komunitas

A : jumlah jenis pada lokasi 1

B : jumlah jenis pada lokasi 2

C : jumlah jenis pada lokasi 1 dan 2

\section{HASIL}

\section{Komposisi dan Morfometri Jenis Sub Ordo Sauria}

Anggota Sub Ordo Sauria yang ditemukan di kawasan hutan primer, hutan sekunder dan pemukiman di Desa Parek Kecamatan Air Besar Kabupaten Landak sebanyak 4 famili dan 7 spesies yaitu Gonocephalus borneensis, Tachydromus sexlineatus, Cyrtodactylus sp., Hemidactylus sp., Draco sp., E. multifasciata dan Apterygodon vittatum. Jenis yang paling banyak ditemukan adalah E. multifasciata sebanyak 5 individu dan jenis paling sedikit yaitu $A$. vittatum hanya ditemukan 1 individu. Jumlah spesies anggota Sub Ordo Sauria di hutan primer ditemukan sebanyak 3 spesies, sedangkan di hutan sekunder dan kawasan pemukiman masing-masing ditemukan 4 spesies (Tabel 2).

Tabel 2. Komposisi Jenis Anggota Sub Ordo Sauria di Desa Parek

\begin{tabular}{cccccc}
\hline \multirow{2}{*}{ Famili } & \multirow{2}{*}{ Spesies } & \multicolumn{3}{c}{ Jumlah Individu } & \multirow{2}{*}{ FK (\%) } \\
\cline { 3 - 5 } Scincidae & Eutropis multifasciata & - & + & + & 66,6 \\
& Apterygodon vittatum & - & - & + & 33,3 \\
Gekkonidae & Hemidactylus sp. & - & - & + & 33,3 \\
& Cyrtodactylus sp. & + & - & - & 33,3 \\
Agamidae & Draco sp. & + & + & - & 66,6 \\
& Gonocephalus borneensis & + & + & - & 66,6 \\
Lacertidae & Tachydromus sexlineatus & - & + & + & 66,6 \\
\hline & Jumlah Jenis & 3 & 4 & 4 & \\
\hline
\end{tabular}

Keterangan : HP (Hutan Primer), HS (Hutan Sekunder), Pm (Pemukiman), dan FR (Frekuensi kehadiran).

Tabel 3. Morfometri Anggota Sub Ordo Sauria di Desa Parek

\begin{tabular}{cccccccc}
\hline Morfologi & Em & Gb & Ts & Hsp & Csp & Dsp & Av \\
\hline PM (mm) & $13,2-16,9$ & $17,1-21,5$ & $8,5-9,2$ & $8,7-9,7$ & $15,9-16,5$ & $8,1-9,5$ & 10,1 \\
PA (mm) & $43,2-47,5$ & $46,2-51,7$ & $28,6-31,1$ & $22,5-26,4$ & $36,8-37,5$ & $38,1-48,5$ & 28,1 \\
PT (mm) & $96,3-101,1$ & $98,2-101,1$ & $55,3-59,4$ & $52,4-61,4$ & $80,9-81,5$ & $65,7-82,3$ & 59,3 \\
PE (mm) & $182,5-191,3$ & $241,1-356,2$ & $151,7-243,1$ & $43,4-59,3$ & $114,2-124,1$ & $101,2-113,4$ & 104,2 \\
PH (mm) & $12,2-13,3$ & $20,5-26,2$ & $6,1-7,2$ & $6,1-10,9$ & $12,2-13,9$ & $10,3-10,7$ & 9,3 \\
PR (mm) & $11,4-12,2$ & $20,6-23,2$ & $6,1-7,0$ & $5,7-9,4$ & $11,2-12,1$ & $8,9-10,5$ & 8,3 \\
PF (mm) & $13,8-15,2$ & $28,9-35,2$ & $8,1-8,4$ & $7,5-14,3$ & $15,8-16,7$ & $10,5-11,8$ & 11,1 \\
PTi (mm) & $12,5-14,2$ & $31,5-32,6$ & $7,8-8,3$ & $6,3-13,7$ & $15,3-16,7$ & $10,9-11,6$ & 12,1 \\
\hline
\end{tabular}

Keterangan : panjang mulut (PM), panjang aksilla (PA), panjang tubuh (PT), panjang ekor (PE), panjang humerus $(\mathrm{PH})$, panjang radius (PR), panjang femur (PF), panjang tibia (PTi), E. multifasciata (Em), G. borneensis (Gb), Hemidactylus sp.(Hsp), Cyrtodactylus sp. (Csp), Draco sp. (Dsp) dan Apterygodon vittatum (Av). 
Tabel 4. Indeks Similiritas Anggota Sub Ordo Sauria di Desa Parek

\begin{tabular}{cccc}
\hline Lokasi & HP & HS & Pm \\
\hline HP & 0,00 & 57,14 & 0,00 \\
HS & 57,14 & 0,00 & 50,00 \\
Pm & 0,00 & 50,00 & 0,00 \\
\hline
\end{tabular}

Keterangan : HP (Hutan Primer), HS (Hutan Sekunder) dan Pm (pemukiman).

Tabel 5. Parameter Lingkungan di Desa Parek

\begin{tabular}{lccc}
\hline \multirow{2}{*}{ Parameter } & \multicolumn{3}{c}{ Lokasi Penelitian } \\
\cline { 2 - 4 } & HP & HS & Pm \\
\hline Kelembaban Udara (\%) & $83-91$ & $72-80$ & $60-75$ \\
Suhu Udara $\left({ }^{0} \mathrm{C}\right)$ & $25-29,8$ & $28,8-33,6$ & $28,4-33,7$ \\
Intensitas cahaya (Lux) & $191-209$ & $278-547$ & $963-1301$ \\
\hline
\end{tabular}

Keterangan : HP (Hutan Primer), HS (Hutan Sekunder) dan Pm (Pemukiman).

\section{PEMBAHASAN}

Anggota Sub Ordo Sauria yang ditemukan di kawasan hutan primer, hutan sekunder dan pemukiman di Desa Parek sebanyak tujuh jenis yaitu Gonocephalus borneensis, Tachydromus sexlineatus, Hemidactylus sp., Cyrtodactylus sp., Draco sp., Eutropis multifasciata dan Apterygodon vittatum yang termasuk dalam 4 famili yaitu Scincidae, Gekkonidae, Agamidae dan Lacertidae. Jumlah spesies yang diperoleh dalam penelitian ini lebih banyak, jika dibandingkan penelitian yang pernah dilakukan oleh Apriyanto et al. (2015) yang menemukan 6 spesies anggota Sub Ordo Sauria di Kecamatan Sungai Ambawang. Spesies yang diperoleh dalam penelitian Apriyanto et al (2015) yaitu, Aphanoitis sp., Tachydromus sexlineatus, Cyrtodactylus sp., Draco sp., Eutropis multifasciata dan Apterygodon vittatum, sedangkan jenis $G$. borneensis dan Hemidactylus sp. tidak ditemukn dalam penelitian tersebut. Hal ini disebabkan oleh perbedaan lokasi penelitian. Hemidactylus sp. merupakan spesies yang ditemukan hanya pada lokasi pemukiman. Penelitian yang dilakukan oleh Apriyanto et al. (2015) pada tiga lokasi yaitu hutan primer, hutan sekunder dan hutan tembawang, sedangkan pada penelitian ini dilakukan pada hutan primer, hutan sekunder dan pemukiman.

Eutropis multifasciata memiliki tubuh yang berwarna coklat dan bintik-bintik putih, memiliki sisik yang kasar pada bagian punggung serta memiliki warna merah kekuningan pada sisi tubuh. Menurut Das (2004), E. multifasciata memiliki sisik dorsal dengan 3-4 kells, berwarna coklat perunggu, bagian sisi tubuh terdapat berkas berwarna merah kekuningan. E. multifasciata yang ditemukan selama penelitian memiliki panjang tubuh berkisar antara 96,34-101,14 mm, sedangkan bagian ekor $E$. multifasciata memiliki panjang berkisar antara 182,53-191,28 mm. Menurut Malkmus et al. (2002), tubuh E. multifasciata umumnya dapat mencapai $25 \mathrm{~cm}$.

Eutropis multifasciata merupakan jenis yang paling banyak ditemukan berjumlah lima individu. Jenis ini ditemukan di permukaan tanah pada hutan primer dan sekunder. Scincidae khususnya $E$. multifasciata merupakan jenis kadal yang mampu beradaptasi dengan kondisi lingkungan. Kemampuan adaptasi E. multifasciata dipengaruhi kemampuan termoregulasi dan menghindari predator, sehingga dapat ditemukan diberbagai macam habitat (Das, 2010). Scincidae memiliki respon dan gerak yang cepat serta aktif dalam berburu (Kurniati, 2000). Sifat yang dimiliki tersebut membuat Scincidae mampu merespon bahaya yang ada, menghindari, berdaptasi dan tidak kesulitan dalam memperoleh makanan. Kelompok ini juga banyak melakukan aktivitasnya di tempat terbuka dan semak-semak kering.

Jenis yang paling sedikit ditemukan pada penelitian ini adalah Apterygodon vittatum hanya ditemukan satu individu. A. vittatum merupakan anggota Sub Ordo Sauria yang memiliki sifat hidup arboreal yaitu lebih banyak melakukan aktivitasnya di pepohonan. Menurut Malkmus et al. (2002), A. vittatum memiliki rentang toleransi yang tinggi terhadap suhu, sehingga keberadaannya dapat ditemukan pada bagian tengah sampai ke bagian atas pohon saat siang hari, namun demikian $A$. 
vittatum toleransi yang rendah terhadap cahaya sehingga lebih banyak melakukan aktivitas di pohon.

Apterygodon vittatum pada lokasi penelitian ditemukan di pohon, memiliki warna coklat dengan garis hijau dan hitam dari kepala sampai ke tubuh serta memiliki bintik-bintik putih. Menurut Apriyanto et al. (2015), A. vittatum memiliki ciri dengan tubuh berwarna hijau dengan bintik-bintik putih dan ditemukan pada mikrohabitat pohon. Menurut Malkmus et al. (2002), A. vittatum memiliki kelopak mata yang ditutupi oleh sisiksisik kecil, memiliki lubang telinga yang kecil berbentuk oval. Hasil pengukuran A. vittatum memiliki panjang tubuh 59,31 $\mathrm{mm}$ dan panjang ekor $104,17 \mathrm{~mm}$.

Anggota dari Gekkonidae merupakan yang paling banyak ditemukan di ketiga lokasi penelitian (8 individu) yaitu dari genus Hemidactylus sp. dan Cyrtodactylus sp. Genus ini memiliki struktur kulit yang berbintil-bintil, dapat mengeluarkan bunyi, dapat memutuskan ekor sebagai pertahanan diri untuk mengelabui predator dan aktif pada malam hari (Malkmus et al., 2002). Berdasarkan penelitian yang telah dilakukan, genus Hemidactylus sp. hanya ditemukan di kawasan pemukiman. Hasil pengukuran panjang tubuh Hemidactylus sp. berkisar antara 52,43-61,47 mm. Cyrtodactylus sp. ditemukan di kawasan hutan primer pada tempat yang berbatu. Menurut Malkmus et al. (2002), Cyrtodactylus sp. memiliki tubuh ramping dengan sisik kecil dan berbentuk kerucut. Hasil pengukur Cyrtodactylus sp., tubuhnya memiliki panjang berkisar antara 80,94-81,56 mm dan panjang ekor 114,17-124,05 mm. Malkmus et al. (2002) menyatakan bahwa panjang total Cyrtodactylus sp. mencapai $180 \mathrm{~mm}$.

Famili dari Lacertidae yang ditemukan dalam penelitian ini adalah Tachydromus sexlineatus. $T$. sexlineatus merupakan kadal yang memiliki tubuh ramping dan ekor panjang, berwarna coklat dengan garis hijau kekuningan. Menurut Das (2004), T. sexlineatus memiliki ekor panjang mencapai 3-5 kali panjang tubuh, dapat dijumpai di padang rumput, sisik menyerupai piring, memiliki warna coklat pada bagian dorsal dengan garis hijau sampai ke pangkal ekor. Kadal ini memiliki kemampuan memutuskan ekornya untuk mengelabui predator. Hasil pengukuran $T$. sexlineatus panjang tubuh berkisar antara $55,34-59,44 \mathrm{~mm}$ dan panjang ekor 151,7-243,13. Menurut Das (2004), panjang tubuh $T$. sexlineatus dapat mencapai $61 \mathrm{~mm}$.

Famili Agamidae yang ditemukan dalam penelitian ini adalah Gonocephalus borneensis dan Draco sp.. Gonocephalus borneensis merupakan kadal dari famili Agamidae yang ditemukan di hutan primer dan hutan sekunder dengan jumlah 2 individu. $G$. borneensis memiliki alat tambahan berupa dorsal crest, pada bagian dorsal memiliki garis-garis coklat, pada lateral terdapat corak bulat berwarna hijau dan memiliki warna yang lebih terang pada bagian tengahnya. Menurut Malkmus et al. (2002), G. borneensis memiliki tubuh yang kokoh, sisiksisik berbentuk lanset dan rapat. Hasil pengukuran Gonocephalus borneensis memiliki panjang tubuh (SVL) berkisar antara 98,26-101,19 $\mathrm{mm}$ dan panjang ekor (TL) berkisar antara 241,14-356,23 mm. Menurut Malkmus et al. (2002), panjang tubuh (SVL) Gonocephalus borneensis dapat mencapai kisaran antara 90-136 mm dan panjang ekor (TL) 215-310 $\mathrm{mm}$.

Draco sp. merupakan salah satu anggota sub ordo Sauria yang unik karena memiliki organ tambahan seperti sayap yang digunakan untuk terbang. Draco sp. memiliki tubuh yang sangat langsing, termasuk dalam kelompok kadal berukuran kecil dengan SVL hingga $140 \mathrm{~mm}$, memiliki dua sayap (patagia) yang dapat dibentangkan dan memiliki banyak warna (Malkmus et al., 2002). Pada penelitian ini Draco sp. yang ditemukan sebanyak 4 individu, terdiri dari 1 individu di hutan primer dan 3 individu di hutan sekunder. Hasil pengukuran Draco sp. memiliki panjang tubuh berkisar antara 65,76-82,35 $\mathrm{mm}$ dan panjang ekor berkisar antara 101,26-113,45 $\mathrm{mm}$.

Berdasarkan hasil penelitian diketahui keberadaan anggota Sub Ordo Sauria lebih banyak ditemukan di kawasan pemukiman dan jumlah individu paling sedikit ditemukan pada kawasan hutan primer. Jenis yang ditemukan di kawasan pemukiman sebagian besar termasuk kadal terestrial yang tidak terganggu dengan adanya aktivitas manusia, seperti Tachydromus sexlineatus, Eutropis multifasciata dan Apterygodon vittatum.

Kawasan pemukiman paling yang banyak ditemukan anggota Sub Ordo Sauria, dikarenakan tempat tersebut merupakan kawasan terbuka sehingga mendapatkan cahaya matahari yang cukup. Anggota Sub Ordo Sauria termasuk hewan ektotermal yang membutuhkan cahaya matahari 
untuk menjaga kondisi suhu tubuh agar tetap stabil. Menurut Juniarmi et al. (2014) anggota Sub Ordo Sauria merupakan hewan ektotermal, yaitu membutuhkan sumber panas dari lingkungan untuk melakukan metabolisme, sehingga sering dijumpai berjemur pada pagi hari dan akan berjemur sampai mencapai suhu tubuh yang dibutuhkan kemudian bersembunyi atau melanjutkan aktivitasnya. Hal ini menyebabkan jenis sub ordo Sauria yang ditemukan di kawasan hutan primer lebih sedikit dibandingkan kawasan pemukiman.

Anggota Sub Ordo Sauria paling sedikit ditemukan di hutan primer yaitu Gonocephalus borneensis, Crytodactilus sp. dan Draco sp.. Hal ini disebabkan, karena hutan primer terdapat pohon-pohon tinggi yang menutupi permukaan tanah dari sinar matahari, sehingga anggota Sub Ordo Sauria melakukan aktivitas di atas pohon untuk mendapatkan sinar matahari.

Jenis Sub Ordo Sauria yang paling banyak ditemukan adalah E.multifasciata dari famili Scincidae. E. multifasciata merupakan anggota Sub Ordo Sauria yang umum ditemukan pada lokasi yang banyak terdapat serasah pada permukaan tanah. Ketiga lokasi penelitian ini memiliki banyak serasah, sehingga menyediakan mikrohabitat yang sesuai untuk E. multifasciata. E. multifasciata juga membutuhkan cahaya matahari selain serasah untuk menjaga suhu tubuhnya tetap stabil. Oleh karena itu, E. multifasciata tidak ditemukan di kawasan hutan primer karena cahaya matahari yang sampai ke lantai hutan primer sangat sedikit. Menurut Juniarmi et al. (2014), E. multifasciata menyukai tempat yang banyak serasah karena lebih lembab dan sebagai tempat bersembunyi, selain itu juga $E$. multifasciata membutuhkan cahaya matahari yang sampai ke lantai hutan agar suhu tubuhnya tetap stabil.

Berdasarkan penelitian yang dilakukan di kawasan hutan primer, hutan sekunder dan pemukiman di Desa Parek diperoleh nilai indeks similaritas antara hutan primer dan hutan sekunder sebesar $57.14 \%$, nilai indeks similaritas antara hutan sekunder dan pemukiman sebesar $50,00 \%$, dan nilai indeks similaritas antara hutan primer dan pemukiman sebesar $0,00 \%$. Berdasarkan hasil penelitian yang dilakukan pada ketiga lokasi diketahui bahwa nilai kesamaan tertinggi pada pasangan lokasi hutan primer dan sekunder $(57,14 \%)$. Hal ini bisa terjadi karena lokasi yang ditemukan sub ordo Sauria antar lokasi tidak berjauhan. Menurut Alikodra (2002), letak geografis pada suatu wilayah dapat menentukan jumlah populasi. Menurut Suin (2002), bahwa dua komunitas yang dapat dikatakan mirip jika nilai kesamaannya $>50 \%$, jadi pasangan lokasi tersebut dapat dikatakan mempunyai komunitas yang mirip dan diduga disebabkan oleh kesamaan kondisi habitat yang sesuai dengan anggota Sub Ordo Sauria.

Kondisi faktor lingkungan di kawasan hutan primer, hutan sekunder dan pemukiman di Desa Parek masih mampu mendukung keberlangsungan hidup dari sub ordo Sauria. Suhu udara yang diperoleh di hutan primer berkisar $25-29,8{ }^{\circ} \mathrm{C}$, di hutan sekunder berkisar $28,8-33,6{ }^{\circ} \mathrm{C}$ dan di pemukiman berkisar $28,4-33,7^{\circ} \mathrm{C}$. Anggota Sub Ordo Sauria merupakan hewan ektotermal yaitu memerlukan sumber panas dari luar untuk melakukan kegiatan metabolismenya. Reptil akan berjemur sampai mencapai suhu tubuh yang dibutuhkannya dan kemudian bersembunyi atau melanjutkan kegiatannya (Halliday dan Adler, 2000).

Kelembaban udara merupakan salah satu faktor lingkungan yang sangat mempengaruhi anggota dari subordo Sauria. Hal ini dikarenakan anggota sub ordo Sauria merupakan hewan poikiloterm. Tingkat kelembaban yang optimal bagi kehidupan anggota sub ordo Sauria yaitu 70-90\% (Primack, 1998). Berdasarkan penelitian yang telah dilakukan di kawasan hutan primer, hutan sekunder dan pemukiman di Desa Parek diperoleh kelembaban di hutan primer $83-91 \%$, hutan sekunder $72-80 \%$ dan pemukiman $60-75 \%$. Hal ini menunjukan bahwa ketiga lokasi tersebut cocok untuk kehidupan anggota Sub Ordo Sauria.

Intensitas cahaya yang diukur di kawasan hutan primer, hutan sekunder dan pemukiman di Desa Parek yaitu 191-209 lux pada hutan primer, 278-547 lux di hutan sekunder dan 963-1301 di pemukiman. Intensitas cahaya pada tiga lokasi berkisar 191-1301 lux. Intensitas cahaya penting bagi kehidupan Anggota Sub Ordo Sauria, karena Anggota Sub Ordo Sauria memanfaatkan cahaya matahari untuk menghangatkan tubuh dengan berjemur agar suhu tubuh tetap stabil. Menurut Juniarmi et al. 2014, anggota sub ordo Sauria membutuhkan sumber cahaya matahari yang sampai ke lantai hutan yang dimanfaatkannya untuk menjaga stabilitas suhu tubuhnya dengan cara mengabsorbsi panas dari sinar matahari. Anggota Sub Ordo Sauria juga dapat dijumpai ketika intensitas cahaya mulai naik dan sampai ke daerah yang terbuka. 


\section{DAFTAR PUSTAKA}

Alikodra, HS, 2002, Pengelolaan Satwa Liar, Jilid 1, bogor, Fakultas Kehutanan, Institut Pertanian Bogor.

Amri, S, Nurdjali, B \& Sihaan, S, 2015, Keanekaragamaan Jenis Reptil Ordo Squamata Di Kawasan Hutan Lindung Gunung Semahung Desa Sebatih Kecamatan Sengah Temila Kabupaten Landak, Jurnal Hutan Lestari, Vol 3 (1) : 30-34.

Apriyanto, P, Yanti, A, H \& Setyawati, T, R, 2015, Keragaman Jenis Kadal Sub Ordo Sauria Pada Tiga Tipe Hutan di Kecamatan Sungai Ambawang, Jurnal Protobiont, Vol. 4 (1) : 108114.

Badan Perencanaan Pembangunan Nasional (BAPPENAS), 1993, Biodiversity Action Plan For Indonesia, Ministry of National Development Planning/National Development Planning Agency, Jakarta.

Das, Indraniel, 2004, Lizards Of Borneo, Natural History Publications (Borneo), Kinabalu.

Das, Indraniel, 2010, A Field Guide To The Reptiles Of South-East Asia, New Holland, London.

Endarwin, W, 2006, Keanekaragaman Jenis Reptil dan Biologi Cyrtodactylus cf fumosus di Taman Nasional di Bukit Barisan Selatan LampungBengkulu, Skripsi, Institut Pertanian Bogor, Bogor <http://repository.ipb.ac.id/handle>.
Halliday, T \& K, Adler, 2000, The Encyclopedia Of Reptiles and Amphibians. Facts on File Inc, New York.

Hickman, CP, LS Robert \& Larson, 2003, Animal Diversity, Mc Graw-Hill Companies, Inc, North America.

Juniarmi, R, Nurdin, J, \& Zakaria, IJ, 2014, Kepadatan Populasi dan Distribusi Kadal (Mabouya multifasciata. Kulh) Di Pulau-Pulau Kecil Kta Padang, Jurnal Biologi Universitas Andalas, Vol. 3(1) : 51-56 (ISSN : 20303-2162).

Kurniati, H, Tjkrawidjaja, A, H \& Maryanto, I, 2000, Analisis ekologi kebiasaan makan kadal (Mabouya multifasciata) di Kebun Raya Indonesia Cabang Bali (Lacertilia : Scinidae), Penelitian Hayati, Vol. 3 : 73-79

Malkmus, R Manthey, U, Vogel, G, Hoffman, \& Dan J, 2002, Amphibians and Reptiles of Mount Kinabalu (North Borneo), A,R,G,Gantner Verlag KG', Rugell, <http://www.landmuseum.at>

Odum, E, P, 1971, Fundamental of Ecology, WE Sounders, Philadelphia.

Suin, N, M, 2002, Metoda Ekologi, Padang: Penerbit Universitas Andalas.

Yusuf, LR, 2008, Studi Keanekaragaman Jenis Reptil Pada Beberapa Tipe Habitat Di EKS-HPH PT RKI Kanbupaten Bungo Propinsi Jambi, Skripsi, Fakultas Kehutanan ITB, Bogor. 